\title{
PAEDIATRICS IN FREETOWN, SIERRA LEONE
}

\author{
BY \\ F. STEPHEN CARTER* \\ From the Connaught Hospital, Freetown, Sierra Leone
}

(RECEIVED FOR PUBLICATION NOVEMBER 14, 1960)

The Colony of Sierra Leone originated in the sale and cession of a portion of land to Captain John Taylor in 1788 which was placed under the protection of the British Government. The main purpose of the Colony in its inception was to secure a home on the African continent for a number of natives of Africa and some others who, due to various circumstances, had been separated from their countries of origin and were destitute in and about London. Within a few years their numbers had been increased by Africans returning from the New World, notably the West Indies and Nova Scotia. Today $25 \%$ of the Africans in the Colony, which now covers an area of 256 square miles, are settlers and their descendants. Apart from these, the African population is tribal, mainly Mende and Temne (Colonial Office List, 1959).

Freetown, the capital, is a seaport with a fine natural harbour and a population approaching 100,000 . There are two distinct seasons: the dry season from November to April, and the wet season extending over the rest of the year, the heaviest rainfall occurring in July and August. According to my own rain gauge at Hill Station, a residential area about four miles out of Freetown and 800 feet above sea-level, the annual rainfall varied from 144 to 177 inches during the four-year period that I was in Sierra Leone.

The observations recorded in this paper were made at the Connaught Hospital, Freetown, from October 1955 to September 1959, with a detailed analysis of admissions during the last six months, during which period, through a temporary shortage of staff, I had undivided control of the children's medical ward.

The Connaught Hospital was built in 1912 and although it has a number of unsatisfactory features by modern standards, such as lack of water-borne sanitation, the hospital has served Colony and Protectorate well for nearly half a century. It is a general hospital of about 250 beds, in which there is a paediatric medical ward of 19 cots, an eight-

\footnotetext{
* Present address: Queen Elizabeth Hospital, Aden.
}

bedded mothers-and-babies ward, and an assortment of side rooms where semi-isolation can be achieved for about six children. In addition there is a smaller ward in the Surgical Unit, but these children have not been included in this paper.

During the six months from mid-March to midSeptember 1959 , there were 422 admissions to the paediatric medical ward of infants or children under 11 years old. There were 105 deaths, giving a mortality rate of very nearly $20 \%$. Many infants were admitted in a moribund state, and were brought into the Hospital by their parents-not to be restored to health-but that a death certificate might be obtained, thereby pacifying the Registrar of Deaths and facilitating the disposal of the corpse. On these occasions, parental grief at the loss of a child was often masked by a stoical resignation to the inevitable, and there were many instances when I was left with the impression that a child's life was considered of little value, even to the extent that on one occasion the parents were blatantly hostile when an apparently moribund infant was resuscitated successfully. This 'death-certificatecomplex' is illustrated in Table 1 where the duration of survival after admission among the fatal cases is recorded. Of 102 fatal cases no fewer than 44 $(43 \%)$ died within 12 hours of admission, of which $27(26 \%)$ lived less than six hours.

TABLE 1

DURATION OF SURVIVAL AFTER ADMISSION IN 102 FATAL CASES

\begin{tabular}{|c|c|c|c|}
\hline \multicolumn{4}{|c|}{ Duration of Survival } \\
\hline \multicolumn{3}{|c|}{ Time after Admission } & \multirow{2}{*}{$\begin{array}{c}\text { Nos. } \\
27 \\
17 \\
16\end{array}$} \\
\hline $\begin{aligned}<6 \text { hrs } & \ldots \\
6-12 \text { hrs } & \ldots \\
12-24 \text { hrs } & \ldots\end{aligned}$ & $\begin{array}{l}\cdots \\
\cdots \\
\cdots\end{array}$ & $\begin{array}{l}\cdots \\
\cdots \\
\cdots\end{array}$ & \\
\hline \multicolumn{2}{|c|}{ Total in first $24 \mathrm{hrs}$} & $\cdots$ & 60 \\
\hline $\begin{array}{l}24-48 \text { hrs } \ldots \\
3-7 \text { days } . . \\
\text { In second week } \\
>2 \text { weeks } . .\end{array}$ & $\begin{array}{l}\cdots \\
\cdots \\
\cdots\end{array}$ & $\begin{array}{l}\cdots \\
\cdots \\
\cdots\end{array}$ & $\begin{array}{r}15 \\
10 \\
5 \\
12\end{array}$ \\
\hline Total $\ldots$ & . & $\cdots$ & 102 \\
\hline
\end{tabular}


The general pattern of admissions and mortality rates shows similarities with those described by MacGregor (1958) in Ibadan, Western Nigeria, but in his series of 1881 about half were infants under 1 year, compared with only a quarter in the present series. The overall mortality rates of $26 \%$ and $20 \%$ respectively are both indicative of the unsolved problems facing the health authorities in their task of educating the general population in hygiene and preventive medicine. MacGregor found a constant mortality rate of about $30 \%$ up to 6 years and thereafter it fell steeply, whereas in this series the infant mortality rate was just over $40 \%$ for the first year, and then fell to about $25 \%$ for the next four years, after which there was another sudden fall in the sixth year.

Table 2 shows the number of infants and children in different age groups and the mortality rates among those admitted to the ward. Unfortunately a number of children in the 8-11 year group had to be admitted to the adult wards due to lack of accommodation, and these have had to be excluded from the investigation. The age of the child was usually a matter of speculation by the ward sister and myself as, although the date of birth of a child from Creole families was usually known, those of Temne or Mende stock were rarely remembered or registered.

TABLE 2

AGE OF ADMISSION AND MORTALITY RATES ACCORDING TO AGE

\begin{tabular}{|c|c|c|c|c|}
\hline Age & & No. Admitted & No. Died & $\begin{array}{c}\text { Approximate } \\
\text { Mortality Rate } \\
(\%)\end{array}$ \\
\hline $\begin{array}{l}0-6 \mathrm{mths} \\
6-12 \mathrm{mths} \\
1-2 \text { yrs } \\
2-3 \text { yrs } \\
3-4 \text { yrs } \\
4-5 \text { yrs } \\
5-6 \text { yrs } \\
6-8 \text { yrs } \\
8-11 \text { yrs }\end{array}$ & $\begin{array}{l}\ldots \\
\ldots \\
\ldots \\
\cdots \\
\cdots \\
\cdots \\
\ldots\end{array}$ & $\begin{array}{l}50 \\
49 \\
93 \\
58 \\
40 \\
35 \\
24 \\
47 \\
26\end{array}$ & $\begin{array}{r}22 \\
18 \\
28 \\
12 \\
11 \\
6 \\
1 \\
4 \\
3\end{array}$ & $\begin{array}{r}44 \\
37 \\
30 \\
21 \\
28 \\
17 \\
4 \\
8 \\
11\end{array}$ \\
\hline Total & $\ldots$ & 422 & 105 & 20 \\
\hline
\end{tabular}

Although 422 children were admitted, 471 diseases have been recorded. Table 3 indicates the major diseases observed, but it is by no means an indication of all that could have been recorded. Multiple diagnoses are the rule rather than the exception in underdeveloped tropical countries, and only those diseases considered to be a major factor in the child's illness have been included. For instance, a very high incidence of symptomless ascariasis was found, but in only nine children was it considered to be the chief cause of the child's symptoms. Likewise minor degrees (by African standards) of malnutrition and avitaminosis have been ignored, and only where these conditions were the primary cause of admission have they been recorded as such. Indeed, so common was hypoproteinaemia that many children showing oedema of the feet and legs had to be treated as out-patients. This ever-present background of malnutrition in its various forms dominates the practice of paediatrics in tropical Africa.

TABLE 3

THE MAIN CAUSES FOR ADMISSION IN 422 INFANTS AND CHILDREN

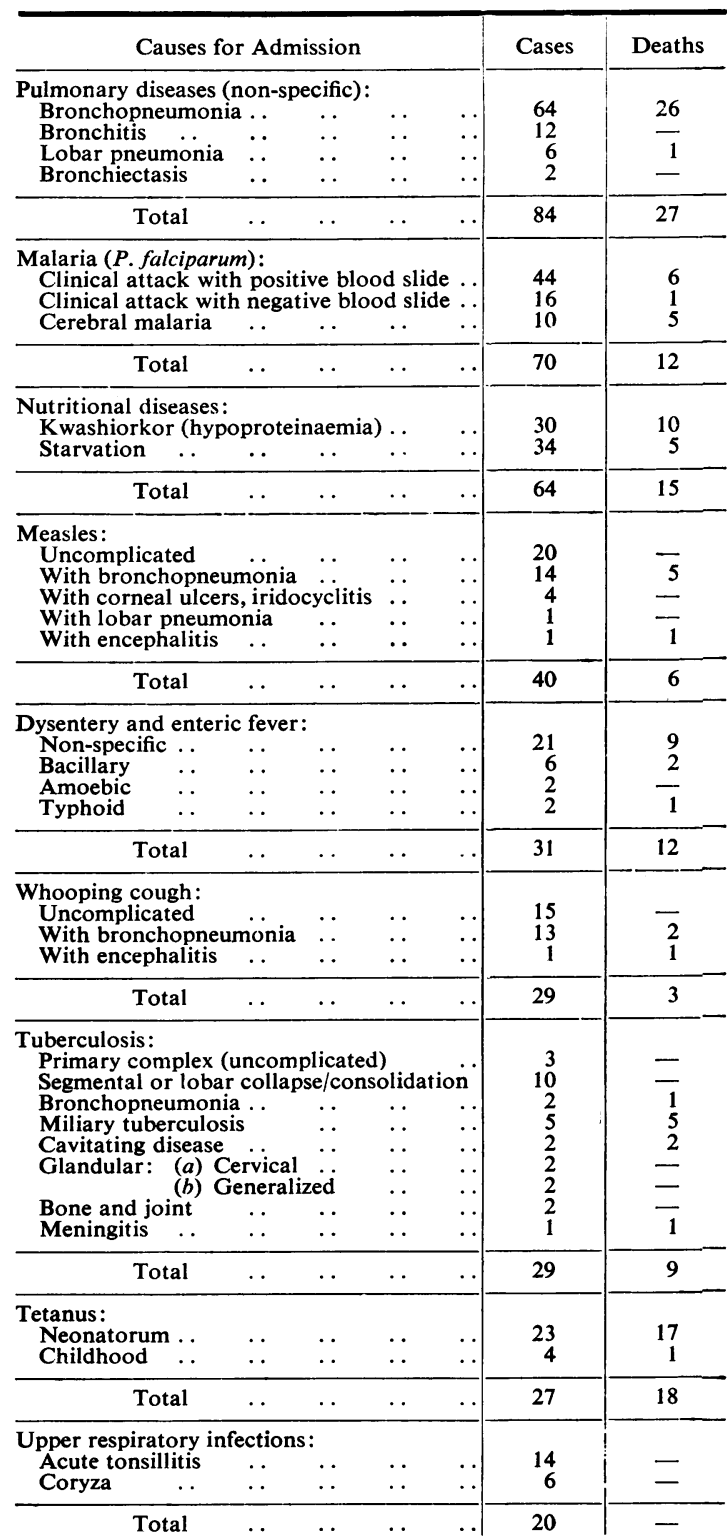


TABLE 3 (contd.)

\begin{tabular}{|c|c|c|c|c|c|}
\hline \multicolumn{4}{|c|}{ Causes for Admission } & \multirow{2}{*}{$\begin{array}{c}\text { Cases } \\
9 \\
9\end{array}$} & \multirow{2}{*}{$\frac{\text { Deaths }}{\frac{3}{-}}$} \\
\hline $\begin{array}{l}\text { Sickle cell crises } \\
\text { Ascariasis }\end{array}$ & 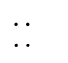 & 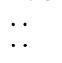 & $\begin{array}{l}\cdots \\
\cdots\end{array}$ & & \\
\hline $\begin{array}{l}\text { Meningitis (pyogenic) } \\
\text { Meningococcal } \\
H . \text { influenzae } \\
\text { Unidentified .. }\end{array}$ & $\begin{array}{l} \\
\cdots \\
\cdots \\
\cdots\end{array}$ & $\begin{array}{l}\cdots \\
\cdots \\
\cdots\end{array}$ & $\begin{array}{l}\cdots \\
\cdots \\
\cdots\end{array}$ & $\begin{array}{l}2 \\
1 \\
3\end{array}$ & $\overline{-}$ \\
\hline Total & $\cdots$ & $\cdots$ & $\cdots$ & 6 & 一 \\
\hline \multicolumn{4}{|c|}{$\begin{array}{l}\text { Dermatological: } \\
\text { Pyogenic lesions } \\
\text { Molluscum contagiosum }\end{array}$} & $\begin{array}{l}5 \\
5\end{array}$ & - \\
\hline Total & $\cdots$ & $\cdots$ & $\cdots$ & 10 & - \\
\hline \multicolumn{4}{|c|}{$\begin{array}{l}\text { Cardiac lesions: } \\
\text { Congenital: }(a) \text { Cyanotic .. } \\
\text { (b) Acyanotic } \\
\text { Acquired: Acute rheumatic carditis }\end{array}$} & $\begin{array}{l}1 \\
3 \\
1\end{array}$ & $\overline{-}$ \\
\hline Total & $\cdots$ & $\cdots$ & $\cdots$ & 5 & - \\
\hline $\begin{array}{l}\text { Infective hepatitis } \\
\text { Osteomyelitis (acute) }\end{array}$ & $\cdots$ & 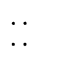 & $\cdots$ & $\begin{array}{l}4 \\
4\end{array}$ & - \\
\hline \multicolumn{4}{|c|}{$\begin{array}{ll}\text { Poliomyelitis: } & \text { (a) Acute } \\
& \text { (b) Longstanding } \\
\end{array}$} & $\begin{array}{l}2 \\
1\end{array}$ & - \\
\hline Total & $\cdots$ & $\cdots$ & $\cdots$ & 3 & - \\
\hline \multicolumn{4}{|c|}{$\begin{array}{llllll}\text { P.U.O. } & & & & \\
\text { Nephritis (Type II) } & \ldots & \ldots & \ldots & \ldots \\
\text { Poisoning } & \ldots & \ldots & \ldots & \ldots \\
\text { Miscellaneous (chickenpox, microcephalus, } \\
\text { polycystic disease of the kidneys) }\end{array}$} & $\begin{array}{r}3 \\
2 \\
2 \\
20\end{array}$ & $\begin{array}{l}- \\
-\end{array}$ \\
\hline $\begin{array}{l}\text { Tota } \\
\text { Maj } \\
\text { Deat }\end{array}$ & $\begin{array}{l}\text { al adn } \\
\text { or dis } \\
\text { ths }\end{array}$ & $\begin{array}{l}\text { ssions } \\
\text { ases } \\
\ldots\end{array}$ & $\begin{array}{l}\cdots \\
\cdots \\
\cdots\end{array}$ & $\begin{array}{l}422 \\
471 \\
105\end{array}$ & \\
\hline
\end{tabular}

\section{Clinical Comments}

Pulmonary Diseases. The pneumonic diseases were the most frequent cause for admission, particularly in the first and second years of life. Routine blood slides were found positive for $P$. falciparum in nearly $25 \%$ of cases. A 'break-through' attack of latent malaria often occurs in acute infections, but in my opinion, the reverse process occurs not infrequently, and a genuine attack of malaria with its rigors, fever, sweating, and chilling of the body can predispose to pneumonia in a child already weakened by infection or malnutrition.

TABLE 4

AGE DISTRIBUTION IN 98 CASES OF PNEUMONIA INCLUDING 27 ASSOCIATED WITH MEASLES OR WHOOPING COUGH

\begin{tabular}{c|c|c}
\hline Age & $\begin{array}{c}\text { No. of } \\
\text { Patients }\end{array}$ & Deaths \\
\hline 0-6 mths & 11 & 5 \\
6-12 mths & 18 & 9 \\
$1-2$ yrs & 26 & 12 \\
$2-3$ yrs & 8 & 4 \\
3- 4 yrs & 9 & 2 \\
4- 5 yrs & 7 & 2 \\
$5-6$ yrs & 9 & - \\
6-8 8rs & 6 & - \\
8-11 yrs & 4 & 34 \\
\hline Total & 98 & 34 \\
\hline
\end{tabular}

Throughout the first three years of life the mortality rate for pneumonic diseases was approximately $50 \%$ (Table 4 ), and this was due, at least partially, to the late stage at which the children were brought to the Hospital, many of them in a moribund condition.

Malaria. Despite continuous public health measures to eradicate the anopheline mosquito, malaria is still prevalent in the outlying districts of Freetown and every patient admitted to the Connaught Hospital has a routine blood slide examined for parasites. Positive slides were obtained in 54 out of the 422 admissions with a further 16 in which a firm diagnosis was made on the clinical picture and the response to specific therapy although parasites were not seen in the blood film; this gave a figure of over $16 \%$ for all admissions.

$P$. falciparum was found in all the positive slides in this six-month period, and other species were only rarely reported in Freetown. The absence of $P$. malariae infections has been noted previously (Carter, 1960) in connexion with the comparative rarity of the nephrotic syndrome, whereas a report by Gilles and Hendrickse (1960) showed the high incidence of nephrosis in Ibadan, Western Nigeria, where $P$. malariae abounds. It is now widely accepted that $P$. malariae is one of the aetiological factors associated with the nephrotic syndrome.

Nutritional Diseases. Although placed only third in the general classification, nutritional diseases ranked by far the most important group in the day-to-day ward routine. Patients suffering from pneumonia or malaria usually left the ward, dead or alive, within five days, whereas children with nutritional diseases were often in residence for several weeks or more, and therefore their numbers seemed to swamp the ward. In addition, minor degrees of malnutrition, avitaminosis or anaemia could be detected in a high proportion of children admitted for other complaints and, because it was almost 'normal', such details were rarely recorded in the final diagnosis in the case records. Florid avitaminosis was rare, but minor degrees of ariboflavinosis in particular were common, and from the knowledge of the poor protein intake in most of the child population, subclinical deficiencies relating to the vitamin $B$ group must have been extremely common. One of the more advanced cases of avitaminosis was seen in a 2-year-old child with symmetrical desquamating dermatitis of the dorsum of the hands, cheilosis, and a vivid magenta tongue. It transpired that her mother was one of the hospital dietitians, who had placed her daughter 
in the care of her grandmother while she herself went out to work.

Children with hypoproteinaemia showed the classical symptoms of the kwashiorkor syndrome in varying degrees, according to the severity of their protein deficiency; oedema of the extremities, face and trunk; depigmentation of the skin and mosaic dermatoses of the limbs with denuded epithelium in the flexural regions of the groins and genitalia; anaemia, hair changes, lethargy and abject misery; all have been adequately described and all were frequently seen in Freetown. Although the general pattern of the disease appears fairly constant in both East and West Africa, the colouration or discolouration of the hair may be distinctly regional.

In Nairobi, Kenya, I noted that the hair in infants with kwashiorkor was grey and only rarely had a faint ginger tint. On driving from Nairobi to Kampala (about 500 miles), and particularly after entering Uganda, the ginger tint became increasingly common and two or three vivid redheads were usually seen by the roadside before reaching Kampala. In Freetown, the typical colour of the hair in infants with kwashiorkor was an indifferent mouse-brown without any greyness or ginger tint. The texture of the hair appeared similar in each of the three territories, the curly, tightly packed, lustrous black appearance being lost and replaced by straightened, wispy hair, thinned out almost to baldness in severe cases.

The nutritional diseases have been divided into hypoproteinaemia and starvation, and although the two conditions sometimes merged together, it was usually possible to separate them without difficulty. The infant with kwashiorkor receives a diet high in carbohydrate but lacking in protein, while the starved infant receives little of any foodstuff. In the latter case, the infant appears as a wizened object of skin and bone, but otherwise normal in that there are little changes in the hair, which tends to remain dark and curly, and there are no skin changes apart from its laxity. It was found that infants suffering from pure starvation usually responded to treatment more readily than those with hypoproteinaemia, and the mortality rate was less than half that seen among the protein deficient infants.

Diarrhoea and Vomiting. This followed the usual pattern seen in the United Kingdom when associated with a parenteral infection, but the number of acute non-specific intestinal infections (21 cases or $5 \%$ of the total admissions) seems remarkably small when the lack of hygiene among the indigenous population is considered. The high mortality rate indicates that only those seriously ill were admitted, and, in fact, lack of accommodation caused many to be treated as out-patients who would have been admitted if cots had been available. In Ibadan, where there was a much higher proportion of infants admitted in general, MacGregor records that 243 out of 1,881 admissions $(12.4 \%)$ were on account of diarrhoea and vomiting.

Anaemia. Anaemia is not listed among the diseases recorded in Table 3, although by European standards a very high proportion of children had some degree of anaemia. Out of 143 consecutive haemoglobin estimations of children on admission $104(72 \cdot 7 \%)$ had haemoglobin levels of $70 \%$ or less (Table 5). The majority of these was due to iron deficiency; these anaemias responded to oral iron therapy, which was given routinely to all children unless specifically ordered otherwise.

TABLE 5

143 CONSECUTIVE HAEMOGLOBIN ESTIMATIONS MADE AT THE TIME OF ADMISSION

\begin{tabular}{c|c}
$\begin{array}{c}\text { Hb on } \\
\text { Admission } \\
(\%)(\text { Sahli) }\end{array}$ & $\begin{array}{c}\text { No. of } \\
\text { Patients }\end{array}$ \\
\hline$<30$ & 1 \\
$31-40$ & 8 \\
$41-50$ & 18 \\
$51-60$ & 40 \\
$61-70$ & 37 \\
$71-80$ & 24 \\
$>80$ & 15 \\
\hline
\end{tabular}

A few of the younger infants appeared to have a normochromic anaemia that failed to respond to any therapy other than blood transfusion.

Tuberculosis. All children with the exception of neonatal infants were Mantoux tested on admission. The injection consisted of $0.1 \mathrm{ml}$. of a freshly prepared solution of $1: 1,000$ Old Tuberculin. If an indefinite or suspected false negative result were obtained the test was repeated using $1: 100$ O.T. solution. The degree of reaction was observed daily for three days. After excluding those who died or absconded within three days of admission, 222 Mantoux tests were obtained, and the results are recorded in Table 6 , together with an assessment of activity of the disease.

There were several notable differences in the pattern of tuberculosis among the Freetown children compared with those I had seen previously in Nairobi, Kenya (Carter, 1954). In Nairobi, there was fever in excess of $102^{\circ} \mathrm{F}$. in 14 out of 41 cases $(34 \%)$ of primary tuberculosis on admission, whereas this degree of fever was not seen in any of 
the Freetown children in whom the average temperature was just over $100^{\circ} \mathrm{F}$., which is fractionally higher than that seen among children in England (Sheldon, 1943; Paterson and Moncrieff, 1947). Enlargement of the hilar glands was also greater in the Nairobi children where over $54 \%$ were considered to have grossly enlarged glands and no case of calcification was recorded. MacGregor considered the hilar glands among children in Ibadan to be slightly larger than seen among children in England, and this was my impression also in Freetown. It was not uncommon to see calcification of hilar glands also. Fibrosis of lung tissue in tuberculosis was never seen in Nairobi children, but two children in the Freetown series who died had extensive fibrocaseous disease of the adult type,

TABLE 6

THE MANTOUX REACTIONS OF 222 INFANTS AND CHIL.DREN AND ASSESSMENT OF ACTIVITY AMONG POSITIVE OR FALSE NEGATIVE REACTORS

\begin{tabular}{|c|c|c|c|c|}
\hline Age & $\begin{array}{c}\text { No. } \\
\text { of } \\
\text { Patients }\end{array}$ & $\begin{array}{l}\text { No. of } \\
\text { Positive } \\
\text { Reactors }\end{array}$ & $\begin{array}{l}\text { No. of } \\
\text { False } \\
\text { Reactors }\end{array}$ & $\begin{array}{l}\text { No. with } \\
\text { Positive } \\
\text { Lesions }\end{array}$ \\
\hline $\begin{array}{l}1-6 \mathrm{mths} \\
6-12 \mathrm{mths} \\
1-2 \mathrm{yrs} \\
2-3 \mathrm{yrs} \\
3-4 \mathrm{yrs} \\
4-5 \mathrm{yrs} \\
5-6 \mathrm{yrs} \\
6-8 \mathrm{yrs} \\
8-11 \mathrm{yrs}\end{array}$ & $\begin{array}{r}4 \\
10 \\
44 \\
46 \\
25 \\
25 \\
17 \\
36 \\
15\end{array}$ & $\begin{array}{r}2 \\
3 \\
4 \\
3 \\
2 \\
7 \\
5\end{array}$ & $\begin{array}{l}- \\
1 \\
\frac{1}{1} \\
= \\
-\end{array}$ & $\begin{array}{r}-2 \\
4 \\
5 \\
3 \\
1 \\
3 \\
2\end{array}$ \\
\hline Total & 222 & 26 & 3 & 20 \\
\hline
\end{tabular}

one of them being only 4 years old. The general pattern of tuberculosis approximated to that seen in England, which is not surprising, as Freetown, being a seaport and having contact with European countries for several hundred years, has had time to develop a degree of immunity, whereas the hinterland of Kenya has only been exposed to tuberculosis for little more than half a century (Haynes, 1951).

Tetanus. Tetanus was the second greatest cause of death, due largely to the $74 \%$ mortality rate among infants in the neonatal period. It has been suggested by MacGregor that the cut umbilical cord is only liable to become infected for a few hours after birth and if this is true the incubation period can be ascertained with reasonable accuracy. Of 23 neonatal cases, only two out of 17 survived among those whose symptoms had started before the ninth day, whereas four out of six survived among those who developed symptoms between the 10th and 14th days (Table 7).

The onset interval, or the time between the first symptom and the first spasm, was not always easy
TABLE 7

INDICATING THE DATE OF ONSET AND FATE OF 23 CASES OF TETANUS NEONATORUM

\begin{tabular}{r|c|c}
\hline Day of Onset & No. of Infants & Deaths \\
\hline 4 th & 1 & 1 \\
$5, "$ & 7 & 6 \\
$6, "$ & 3 & 3 \\
$7, "$ & 3 & 3 \\
9, & $\frac{2}{2}$ \\
\hline $10-14,$, & 6 & $\frac{2}{2}$ \\
\hline Total & 23 & 17 \\
\hline
\end{tabular}

to assess accurately. The uneducated African mother is very vague in her appreciation of time, but as the first symptom of tetanus neonatorum is the infant's inability to suck (Tompkins, 1958), the mother might be expected to have some idea of the time of onset of the disturbance to this vital function. Tompkins stressed the prognostic value of the onset interval and found that the chances of survival increased steadily the longer it exceeded 24 hours.

Although the number in this series is too small to have any statistical significance, I received the impression that every day the incubation period was prolonged, the chance of survival increased. Even among those who died, death appeared to occur more rapidly and to be more inevitable among those with an incubation period of six days or less than those from seven to 10 days (Table 8). Tompkins had deaths in 79 out of 80 cases $(98.7 \%)$ where the incubation period was seven days or less, compared with 42 out of $55(76.4 \%)$ where the incubation period was over seven days.

Sickle Cell Crises. The incidence of sickle cell disease and trait in Sierra Leone has yet to be established, but there is little doubt, from the frequency with which the condition is seen in Freetown, that the rate is comparable to that recorded in other West African territories, where figures for sicklaemia have varied from approximately $12 \%$ to $23 \%$ (Gelfand, 1957a). Nine children were admitted in sickle cell crises during

TABLE 8

SHOWING THE DURATION OF LIFE AFTER THE FIRST SYMPTOMS IN 16 FATAL CASES OF TETANUS NEONATORUM

\begin{tabular}{c|c|c}
\hline $\begin{array}{c}\text { Incubation } \\
\text { Period } \\
\text { (days) }\end{array}$ & $\begin{array}{c}\text { No. of } \\
\text { Infants }\end{array}$ & $\begin{array}{c}\text { Survival Period } \\
\text { After First Symptoms } \\
\text { (hours) }\end{array}$ \\
\hline $4-6$ & 10 & $\begin{array}{c}7-79 \\
\text { (average 22) } \\
16 \text {-96 } \\
\text { (average 42) }\end{array}$ \\
\hline $7-10$ & 6 & \\
\hline
\end{tabular}


the six months under review and three of them died.

The clinical features of a crisis have been described by many authors including Gelfand (1957b), Wilkinson (1950) and Blackfan, Diamond and Leister (1944). The usual symptoms described are breathlessness, palpitation, weakness, nausea and vomiting, and pains in the limbs and joints; on examination, there may be jaundice with a variable degree of hepatosplenomegaly, tenderness of the limbs, cardiac murmurs and a severe degree of anaemia. In view of the great variety and inconsistency of the symptoms it is easy to overlook the correct diagnosis unless the possibility of the disease is kept persistently in mind. From my own experience, two patients had appendicectomies performed when they were suffering from abdominal symptoms at the onset of a crisis. One of the children was known to have sickle cell disease, but the symptoms were so suggestive of acute appendicitis that it was considered safer to risk removing a normal appendix rather than leave one that might be about to perforate.

The combination of fever, persistent tachycardia, swollen and painful joints, together with cardiac enlargement and systolic murmurs, caused an erroneous diagnosis of acute rheumatic fever on occasions. The diagnosis can be extremely difficult to make if other signs such as jaundice are lacking, and final confirmation of the disease rests in the hands of those in the laboratory.

Headache is almost always mentioned as one of the symptoms of a sickle cell crisis, but I have failed to confirm this among my patients. Latterly, I came to regard its absence as a point in favour of a sickle cell crisis, and the presence of headache to favour rheumatic fever.

The sites of pain, due to thrombotic emboli of sickled cells are not usually confined to the joints but often involve the long bones also. One boy, aged 8 years, who had had crises every two or three weeks from the age of 18 months, could give early warning of an attack as the pain invariably commenced in the sternum, and within a few hours he had agonizing pain involving all his bones and joints so that he could not tolerate anyone touching him. The severity of the pain that may occur in a crisis does not appear to have been sufficiently stressed in the literature. In several children under my care it was clear that they were suffering excruciating pain as severe as any that $I$ have seen in paediatric practice.

Dermatology. Almost all children go barefoot in Freetown and it is not surprising that infections of the feet were commonplace, but, in general, pyogenic lesions were of a minor degree and only sufficiently severe to require admission on five occasions. The commonest skin conditions seen in the children's ward were those related to the kwashiorkor syndrome.

Molluscum contagiosum was frequently seen, but it was unusual for a child to have more than a score of lesions. The sites most commonly affected lay between the mid-axillary line and anterior axillary fold in and just below the armpit, and on the temporal aspect of the forehead. Lesions were frequently seen elsewhere on the face, neck and thorax, and appeared to select surface areas where the skin was of a delicate texture. It was unusual to find molluscum contagiosum on the back of the trunk or the lower limbs.

Yaws is a condition widespread in the Protectorate of Sierra Leone, but comparatively rare in the Colony area. A Yaws Campaign has been carried out for several years in the Protectorate under the auspices of the World Health Organization, and there is every evidence that it is meeting with considerable success. On my arrival in Sierra Leone in 1955, I was informed that there was no yaws in Freetown, but about a year later, a newly-appointed School Medical Officer, the late Dr. I. Rosanelli, disproved this by producing six children for our inspection; she had found them on routine examination among schools in Freetown.

Congenital Lesions. It is difficult to assess the relative frequency of congenital defects with those seen in England. Certain conditions such as pyloric stenosis appear less frequent and I saw only three Rammstedt operations performed in four years; MacGregor did not see a single case of pyloric stenosis during a year in Ibadan, Western Nigeria. In six months, four congenital hearts were noted among in-patients, and several others were referred to me as out-patients. Also admitted to the hospital was one infant with microcephalus and another with polycystic disease of the kidneys. Only one hare-lip and cleft palate was seen during the whole of my stay in Sierra Leone. I often suspected that infants born with obvious and disfiguring abnormalities might have been the victims of deliberate neglect or even infanticide because of the rarity with which they were seen, compared with the relative frequency of invisible lesions such as congenital hearts.

Rheumatism. Only one case of rheumatic fever was seen in this six-month period. The condition is rare in Freetown and I never saw more than two 
cases in any one year. Mitral lesions were found occasionally in the adult population, in whom valvular disease was commonplace, but such lesions were usually due to aortic incompetence of syphilitic origin.

Two children were admitted with Sydenham's chorea in four years, one of them having a severe hemichorea which lasted many weeks. This girl, about 10 years old, developed a systolic murmur in the mitral area shortly after admission, but this faded gradually and was inaudible when I last saw her about one year after the onset of her illness. Chorea must be very rare in Sierra Leone for I showed the child to as many of my African colleagues and nursing staff as possible and none of them had seen the condition previously.

Upper respiratory infections and otitis media were seen much less frequently than in England, and culture of throat swabs almost invariably produced non-specific organisms, haemolytic streptococci being extremely rare.

Virus Infections. Sporadic virus infections were common and there were always patients to be seen in the hospital with infective hepatitis, but we had no outbreak in Freetown of encephalomyelitis such as confronted Rose (1957) in Segbwema in the Protectorate in which nine out of 45 patients were children or adolescents. Acute poliomyelitis was seen occasionally but never in epidemic form. A small outbreak of pleurisy due to a Coxsackie B infection occurred in the summer of 1958, but this was almost confined to young adults.

\section{Methods of Treatment}

Transfusions. All transfusions were given by the intraperitoneal route unless some contraindication was present. The technique described by Carter (1953) was used throughout and the only contraindication that occurred was distension of the abdomen by intestinal gas, which was rarely sufficient to necessitate using another method of administration. In these cases and in tetanus neonatorum the subcutaneous route was used in conjunction with hyaluronidase. In infants with acute dehydration the fluids used most frequently were either half-strength Hartmann's solution or half-strength normal saline with $2.5 \%$ glucose. Blood transfusions for anaemia and hypoproteinaemia were also given by the intraperitoneal route and the observations made by Macdougall (1958) on the efficacy of this method were confirmed.

Intravenous transfusions were given infrequently and only when they could be supervised personally in view of the danger of the circulation being over- loaded. I started using the intraperitoneal method in Kenya in 1952 following two fatal accidents from lack of adequate supervision of intravenous drips, and since then have seen no untoward effects in the course of several thousand transfusions, many of which have been given by the ward sister or staff nurse. I have always been intrigued by the apparent difficulty many Africans have in 'counting against the clock', and this has been true in both Kenya and Sierra Leone. On one occasion when I had started an intravenous blood transfusion in the Connaught Hospital, I was assured by the senior nurse that the drip was running at 12 drops per minute when the actual rate was 92 per minute. MacGregor also records that one or two deaths occurred at University College Hospital, Ibadan, due to cardiovascular effects of transfusion. Apart from the apparent safety and effectiveness of intraperitoneal transfusions, there are the added advantages that the transfusion can be completed within a few minutes and that the child can thereafter be free from restrictions.

Kwashiorkor Syndrome. The usual method of giving a high protein, easily digestible diet was employed at the Connaught Hospital. The standard food used was double-strength skimmed milk, the amount being increased according to the degree of tolerance shown. If the amount was increased too rapidly, diarrhoea often occurred. In addition, intraperitoneal transfusions of blood and/or serum albumen were given. A limited number of $60 \mathrm{ml}$. bottles of serum albumen (equivalent to the albumen content of one pint of blood) were available, and one bottle was given intraperitoneally on admission. It was unusual to note any marked improvement during the first 24 hours but during the second day a marked diuresis frequently occurred with noticeable reduction in oedema. Unfortunately, only 30 bottles were available, and it was impossible to replace them on account of the very considerable expense involved. The therapeutic value, however, was proved beyond doubt. When the method was first employed I expected to see a transient increase in the size of the abdomen due to the attraction of fluid into the abdominal cavity as a result of using a fluid with such high osmotic power. In actual fact this never occurred and the serum must have been adequately absorbed for diuresis to develop so effectively.

Anaemia. Intraperitoneal blood transfusions were given whenever possible, but for a long time blood was almost unobtainable. West Africans are not enthusiastic blood donors and in Freetown they 
usually managed to vanish immediately their blood had been taken for grouping. This was eventually overcome by bleeding the donor before grouping was carried out. Whenever an adult male entered the ward with a child for admission, I guided him to my office and bled him before he had time to cogitate on the prospect. This method increased our supplies of blood at least tenfold, and only on one occasion did $I$ have the misfortune to find I had bled someone who was Group AB. If the blood proved to be incompatible for the donor's own child it could always be used for another infant or infants as there was never a sufficient supply of blood for the ward's requirements. The usual method was to divide a pint of blood between two or three infants and, by using the intraperitoneal route, the whole procedure could be completed in about 20 minutes. If blood were available the transfusions were repeated on two or three occasions at daily intervals.

On one occasion a serious error was made when an infant of about 10 months was given about $250 \mathrm{ml}$. of Group B blood intraperitoneally, the recipient being Group $O$. The mistake was not realized until 24 hours later, but the infant showed no signs of an incompatible transfusion and made excellent clinical progress. The fact that the episode did not end disastrously tends to confirm the observation made by Unger (1921) that for infants under 6 months of age any donor is compatible regardless of blood group, and Tallerman (1958), using cells labelled with radioactive chromium, has confirmed that the donor's red cells are absorbed into the circulation following intraperitoneal transfusions.

When malaria was suspected as being a cause of the anaemia the patient was given anti-malarial therapy. Hendrickse, quoted by MacGregor, found antimalarial therapy alone sufficient to restore the haemoglobin level without having recourse to iron therapy or blood transfusion. However, in the few instances when I tried this method I was not impressed by the rate of improvement, and latterly blood transfusion was employed as the main therapeutic measure, its great value being the increased speed with which an infant could be discharged, thereby relieving the strain on the bed situation.

Tetanus neonatorum. All infants were given anti-tetanus serum immediately on admission in dosages varying from 50,000 to 100,000 units, but I have become increasingly sceptical of its value even in those cases where the injection has been given within a few hours of the onset of the first symptoms. Of more than 120 infants with tetanus neonatorum under my care in Freetown $I$ can remember only one instance where A.T.S. was considered to have altered the outcome of the disease favourably. This occurred in a 5-day-old infant, who was given 100,000 units within four hours of developing trismus and before the onset of spasms. In the 15-month period from October 1955 to February 1957, when over 40 cases of tetanus neonatorum were admitted to the Connaught Hospital not a single infant survived. It was during this period that there was an acute shortage of trained nursing staff and the standard of nursing was at a low ebb, but with the advent of an excellent staff nurse and later, a ward sister with paediatric experience, the mortality rate started to fall and a fatal termination no longer appeared inevitable. I have since felt that the greatest single factor in prognosis rests on the standard of nursing available.

The infants were admitted to the mothers-andbabies ward, and, if possible, placed in a corner of the ward, but no other precautions could be taken against light and noise. It was always difficult to get the co-operation of the mothers to leave their babies in the cots and our experiences were very similar to those described by Jelliffe (1950) in Ibadan. All infants were given daily injections of procaine penicillin for five days. The umbilical region was cleaned with a dilute antiseptic, and a dry dressing was applied, but neither local infiltration with A.T.S. nor umbilectomy was used. Umbilectomy was recommended by Vinnard (1945), but an operation of this nature would be abhorrent to the mind of an African native, who always has a high regard for his umbilicus, and would not tolerate its removal.

Sodium phenobarbitone gr. $\frac{1}{8}-\frac{1}{4}$ was used as a basal sedative and repeated when necessary in conjunction with intramuscular paraldehyde, but the latter was used as infrequently as possible owing to the danger of tissue necrosis. Chloral hydrate was used as an alternative in a dosage of 1-2 gr. when a change in therapy was indicated. Mephenesin elixir was given a prolonged trial, but the drug was considered of little value in producing muscular relaxation in tetanus neonatorum.

More recently a combination of chlorpromazine $10 \mathrm{mg}$. given intramuscularly with sodium phenobarbitone became standard treatment and this proved the most promising method of treatment. Injections of chlorpromazine were required on an average every four hours during the first two or three days, but were discontinued as soon as possible as the injections tended to give rise to hard, indurated lumps. Fortunately, these rarely suppurated. Cole and Robertson (1955) described the successful 
treatment of a 12-day-old infant in Tanganyika with chlorpromazine and our experience confirmed their observations on its value in controlling spasms, although its effect passes off within a few hours.

Tracheotomy was never performed as there was insufficient trained staff available for adequate supervision after the operation, and the dangers of tracheotomy in these conditions were considered to outweigh the likelihood of a favourable result.

Sickle Cell Disease. There is still no known cure for this disease, and blood transfusion is still the most valuable form of therapy to counteract the acute anaemia which develops during a sickle cell crisis. Hopes were raised when Hilkovitz (1957) reported that acetazolamide had reduced the degree of sickling in a child suffering from sickle cell disease, and it was given an immediate trial in Sierra Leone. The news that there was a new drug for this incapacitating disease soon percolated to the African population and within a few weeks the pharmacies in Freetown had no supplies left and the 'black-market' price bounded to five times that of the official price list.

Unfortunately results did not come up to expectations. In those patients who were admitted in the throes of an attack, the drug was given in full dosage as recommended by Hilkovitz and sometimes it was increased still further, but it never appeared to reduce the length or severity of an attack. In the case of the boy already mentioned whose attacks commenced with pain in the sternum, acetazolamide was given to the mother to administer as soon as an attack appeared to be developing, but this failed to alter the pattern of his attacks. It was clearly too expensive a drug for the average patient to receive prophylactically, but even this method was tried on several patients who suffered from frequent crises, but to no avail. Disappointing results have also been recorded by Macdougall and Jacob (1959) and dos Santos and Lehmann (1959).

\section{Comments}

Many of the common diseases of childhood that occur in the United Kingdom were to be seen in Sierra Leone, and the practice of paediatrics in Freetown was not confined to tropical diseases alone. However, even among diseases common to both temperate and tropical climates, there was a great difference in prognosis. The background of malnutrition in its various forms pervaded through all illnesses and, in general, children showed a lack of resilience and an inability to combat serious infection. Most children had no spare flesh upon which to draw when they contracted such debilitating ailments as the common infectious diseases of childhood, and were readily susceptible to secondary infections. Cancrum oris was seen on several occasions, and in the present series two of the four children who developed eye complications during an attack of measles became totally blind.

Certain conditions commonly seen in the United Kingdom were rare, notably the allergic disorders. Asthma was only seen occasionally, but the attacks proved difficult to control. I have never seen infantile eczema in an African in either Kenya or Sierra Leone. My attention was focused on this latter condition in 1958 when I visited the Belgrave Hospital for Children, London, at the invitation of Dr. R. B. Martin, and saw in one session about a dozen infants and children of West Indian extraction with infantile eczema. The other striking feature was their excellent physical development in contrast with that of the children I was accustomed to see in Freetown.

Toxoplasmosis in its acute form in infancy or early childhood was never recognized, and yet I saw over 30 patients with this disease presenting with choroido-retinitis in varying degrees of activity or quiescence during four years in Freetown. The youngest patient was a girl of 12 years and about half of them were still at school or college. The patients invariably complained of some degree of deterioration of vision, and as a number of them were studying for examinations, they usually visited one of the opticians in Freetown with a request for glasses to assist them in reading. A few patients complained of a mild degree of frontal headache such as might occur with eye-strain in addition to impaired vision, but apart from this, toxoplasmosis appeared to be symptomless and more than half the patients were referred to me by opticians.

Treatment employed in treating toxoplasmosis was confined to the use of pyrimethamine (tabs. once or twice daily according to the weight of the patient) for a minimum of three months. In those patients with a recent history of blurring of vision and showing acute choroidoretinitis, improvement was usually noticed between three to six weeks of commencing treatment, but no improvement was seen when the symptoms had been present for six months or longer. The only toxic sign seen after the use of such a large dosage of pyrimethamine was an increase in depth of pigmentation, particularly in the palmar creases of the hands, which, although normally almost free from pigmentation, after three months' therapy were often almost jet-black.

\section{Summary and Conclusions}

An account is given of paediatric experience gained during four years in Freetown, Sierra Leone, 
with an analysis of 422 infants and children who were admitted to the children's medical ward during the last six-month period.

Parental ignorance, fear, and superstition were partly responsible for the high mortality rate in infancy and early childhood. Many children were brought to hospital in a moribund condition, suffering from illnesses which could have been cured if they had been brought earlier. The high incidence of tetanus neonatorum is an example of the degree of ignorance and lack of hygiene to be found among the general population; a lowering of the mortality rate in childhood generally is not likely to be appreciable until education in public health measures becomes effective.

The presence of malnutrition among children was a major factor in the high morbidity and mortality rates, and was due to a combination of poverty and ignorance in dietary matters.

I am indebted to Dr. T. P. Eddy, late Director of Medical Services, Sierra Leone, and to his successor, Dr. H. M. S. Boardman, for their encouragement in the writing of this paper.

\section{REFERENCES}

Blackfan, K. D., Diamond, L. K. and Leister, C. M. (1944). Atlas of the Blond in Children, p. 84. Commonwealth Fund, New York.
Carter, F. S. (1953). Intraperitoneal transfusions as a method of re-hydration in the African child. E. Afr. med. J., 30, 499.

- (1954). Primary tuberculosis in African children. Arch. Dis. Childh., 29, 213.

(1960). Plasmodium malariae in 'Nephrotic syndrome'. Lancet, 1, 1128.

Cole, A. C. E. and Robertson, D. H. H. (1955). Chlorpromazine in the management of tetanus. Ibid., $2,1063$.

Colonial Office List (1959). p. 164. H.M. Stationery Office, London.

Gelfand, M. (1957a). The Sick African, 3rd ed., p. 666. Juta, Capetown.

- (1957b). Ibid., p. 669

Gilles, H. M. and Hendrickse, R. G. (1960). Possible aetiological role of Plasmodium malariae in 'Nephrotic syndrome' in Nigerian children. Lancet, 1, 806.

Haynes, W. S. (1951). Tuberculosis in Kenya, p. 103. Govt. Publ., Nairobi.

Hilkovitz, G. (1957). Sickle-cell disease: new method of treatment. Preliminary report. Brit. med.J., 2, 266.

Jelliffe, D. B. (1950). Tetanus neonatorum. Arch. Dis. Childh., 25,190

Macdougall, Lorna G. (1958). Intraperitoneal blood transfusions in children. Brit. med. J., 1, 139.

- and Jacob, G. (1959). Acetazolamide in the treatment of sickle-cell anaemia. Ibid., 2, 141.

MacGregor, M. (1958). Paediatrics in Western Nigeria. Arch. Dis. Childh., 33, 277.

Paterson, D. and Moncrieff, A. (1947). In A. E. Garrod, F. E. Batten and H. Thursfield's Diseases of Children, 4 th ed., vol. 1 , p. 663. Arnold, London.

Rose, J. R. (1957). An outbreak of encephalomyelitis in Sierra Leone. Lancet, 2,914

dos Santos, W. D. and Lehmann, H. (1959). Acetazolamide in sickle-cell anaemia. Brit. med. J., 2, 139.

She!don, W. (1943). Diseases of Infancy and Childhood, 4th ed., p. 383. Churchill, London.

Tallerman, K. H. (1958). Intraperitoneal blood transfusion. Brit. med. J., 1, 338 .

Tompkins, A. B. (1958). Neonatal tetanus in Nigeria. Ibid., 1, 1382.

Unger, L. J. (1921). Precautions necessary in the selection of a donor for blood transfusion. J. Amer. med. Ass., 76, 9 .

Vinnard, R. T. (1945). Three hundred and fifty-two cases of tetanus. Surgery, 18, 482

Wilkinson, J. F. (1950). The British Encyclopaedia of Medical Practice, 2nd ed., vo!. 1, p. 490. Butterworth, London. 